\title{
The Middle Caddoan Period in the Lower Sulphur River Area
}

Maynard B. Cliff

Unknown

Follow this and additional works at: https://scholarworks.sfasu.edu/ita

Part of the American Material Culture Commons, Archaeological Anthropology Commons, Environmental Studies Commons, Other American Studies Commons, Other Arts and Humanities Commons, Other History of Art, Architecture, and Archaeology Commons, and the United States History Commons

Tell us how this article helped you.

This Article is brought to you for free and open access by the Center for Regional Heritage Research at SFA ScholarWorks. It has been accepted for inclusion in Index of Texas Archaeology: Open Access Gray Literature from the Lone Star State by an authorized editor of SFA ScholarWorks. For more information, please contact cdsscholarworks@sfasu.edu. 


\section{The Middle Caddoan Period in the Lower Sulphur River Area \\ Creative Commons License \\ (c) (1) (9)}

This work is licensed under a Creative Commons Attribution-NonCommercial 4.0 International License 


\section{THE MIDDLE CADDOAN PERIOD IN THE LOWER SULPHUR RIVER AREA}

\section{Maynard B. Cliff}

For purposes of this review, the Lower Sulphur River in Texas includes the area of the Sulphur River basin from the Arkansas border to the eastern edge of Titus County, and encompasses the area of what is today Wright Patman Lake and the White Oak Creek Wildlife Management Area (Figure 1). Traditionally, the Lower Sulphur River area has been tied to cultural constructs defined in the Red River basin, to the north and east. In his ambitious overview of the Caddoan Culture Area, Don Wyckoff (1974) generally placed the Lower Sulphur River area with the cultures of the Great Bend. As defined by current usage in Texas, the Middle Caddoan period dates from A.D. 1200 to A.D. 1400, but it is actually the middle portion of a long period of indigenous Caddoan cultural development, which began anywhere from A.D. 800 to 1000 and lasted until after the arrival of the Europeans. Several researchers (Davis 1970:44; Suhm et al. 1954:171) have suggested that the strongest (and possibly the only) evidence for continuity from the Farly Caddoan period to the Late Caddoan period can be found in the area of the Great Bend of the Red River.

Within the Red River basin, to the north of the Sulphur River, Middle Caddoan settlement patterns include mound sites (with one or more mounds, including temple mounds and burial mounds), sometimes with adjacent village areas and associated nonmound cemeteries (Suhm et al. 1954:172). At the Hatchel site (41BW3), Krieger (1946:213, fn. 42) noted that a "midden mantle" containing Late Caddoan Texarkana phase material overlay two superimposed, flat-topped temple mounds associated with Middle Caddoan Haley phase pottery. The original mound was described as rectangular, about 21 $\mathrm{x} 14 \mathrm{~m}$ in size, with steep sides and indications of a clay ramp on the southern face. Over this had been built a flat-topped "eminence", measuring about 34 x $18 \mathrm{~m}$ and almost $5 \mathrm{~m}$ high. Partially covering both of these structures was the outline of a very large, round structure, almost $17 \mathrm{~m}$ in diameter. This structure contained no definite fire place and only one or two small support posts. According to Krieger, this structure and the two superimposed flat-topped mounds all contained Haley phase pottery (Krieger 1946:213, fn. 42). No burial mound has been identified at the Hatchel site (Suhm et al. 1954:172), and Davis (1970:44) states that no Haley phase burials are known from the Hatchel site at all. To the east of the Hatchel site, the Cabe Mounds site (41BW14) includes a small mound group and three more possible isolated mounds, but their function is presently unknown (Perttula et al. 1995).

Generally, Middle Caddoan sites in this area are located on the flood plains of major streams and their larger tributaries and on upland margins immediately adjacent to flood plains (Suhm, et al. 1954:172). In addition to the mound sites, small farmsteads may be located on natural levees or on high ground overlooking the flood plains. In Texas, the Middle Caddoan component at the Mitchell site (41BW4) may contain occupation midden.

At the mouth of the Sulphur River, in Arkansas, the Haley site contained three mounds, at least one of which was a rectangular temple mound and one a circular flattopped burial mound (Suhm et al. 1954:172). A number of single mound sites have been reported within the lower Sulphur River basin in Texas, including 41BW76 (possibly Late Caddoan), 41BW53, 41CS1 (the Coker Mound), 41CS4 (the T.S. Montgomery Mound), 41RR3 (the T.M. Coles or Mustang Creek Mound--possibly Eariy Caddoan), 41RR190, and 41RR200; but most of these are either undated or only poorly dated (see Perttula 1993). At the present time, only the Coker Mound can be associated with the Middle Caddoan period, having yielded material which has been radiocarbon dated to the fourteenth century A.D. (see Perttula et al., this volume). Middle Caddoan settlement in the lower Sulphur River area appears to consist of small, scattered hamlets, located on old natural levees or on upland edges overlooking the floodplains of both major and minor 


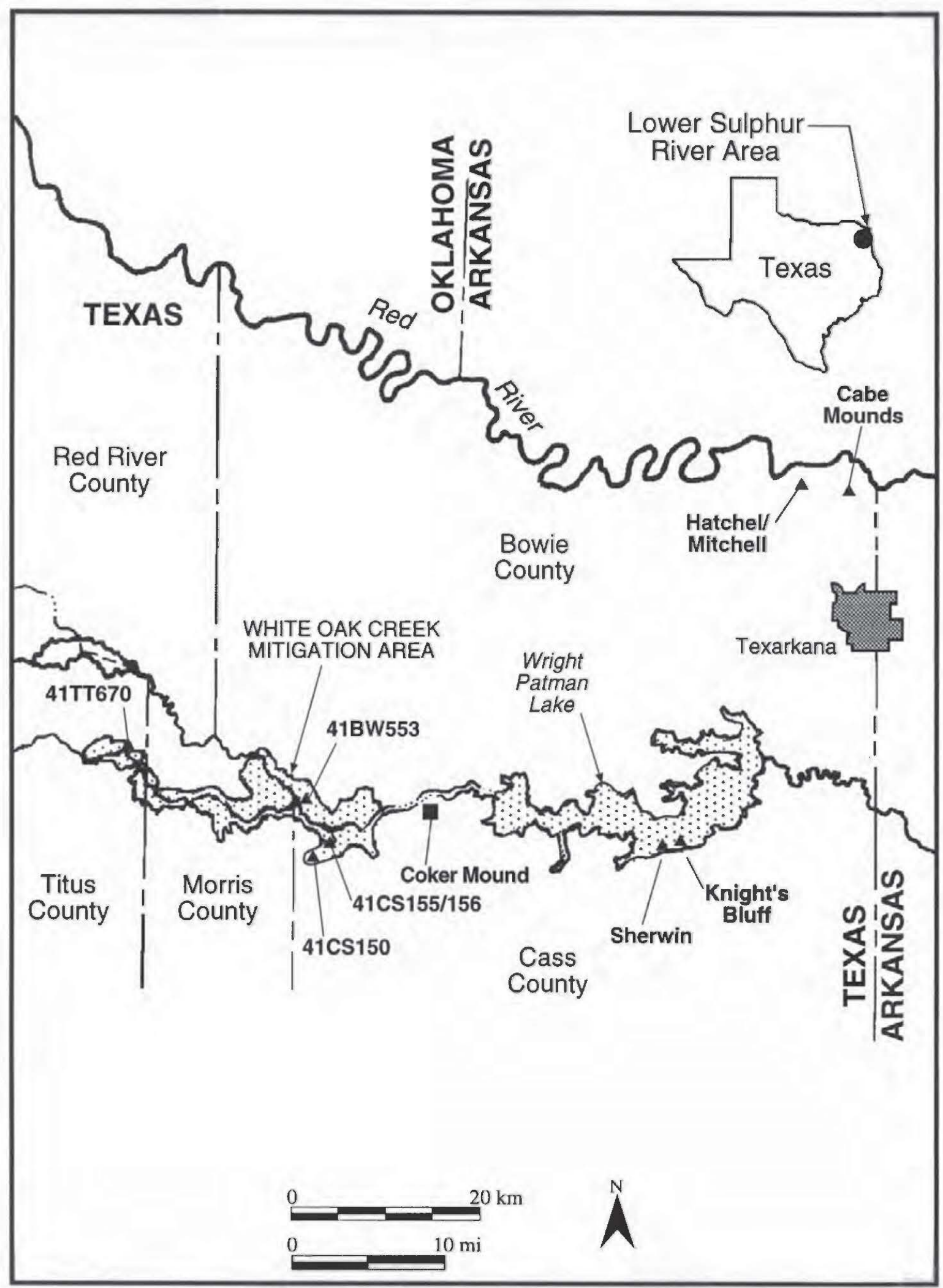

Figure 1. Archeological Sites Mentioned in the Text. 
drainages. These hamlets appear to be characterized by house structures, middens, and possibly small cemetery areas. So far, no large village sites dating to the Middle Caddoan period have been identified in the lower Sulphur River area.

Within the lower Sulphur River area, there is presently little direct evidence of subsistence patterns during the Middle Caddoan period. Agriculture is generally inferred to have been based primarily on maize, and was presumably supplemented by hunting, fishing, and shellfish gathering. In the White Oak Creek area, both site 41CS155/156 and $41 \mathrm{CS} 150$ yielded evidence for the presence of maize during this period, although it was 110t abundant and cannot be taken to indicate intensive maize agriculture (Cliff and Hunt 1995). Exploited wild plants apparently included hickory, walnut, acorn, possibly grape, possibly maygrass, and some form of wild tuber (prairie turnip?). Terrestrial resources included deer, and probably opossum and rabbit; while important aquatic resources included fish, molluscs, and turtle (Cliff and Hunt 1995).

In the Red River basin, Middle Caddoan mortuary remains include both single and multiple burials in extended positions (Krieger 1946:214; Newell and Krieger 1949:203; Suhm et al. 1954:175; Wyckoff 1974). Graves were apparently placed in deep pits in nonstructure mounds and in non-mound cemeteries. In the lower Sulphur River area, small cemeteries which may date to the latter part of the Middle Caddoan period were present at the Knight's Bluff (41CS14) and Sherwin (41CS26) sites at Wright Patman Lake (Jelks 1961). At Knight's Bluff, there were 10 burials excavated in two clusters. All were extended on their backs, all but one were accompanied by mortuary offerings, and all but two were oriented with the head toward the south or east, or somewhere in between. Burial 2 contained two individuals, but the others were single interments. All but two were associated with pottery. At the Sherwin site, eight burials were excavated, most in a single cluster. All were extended on the back, and seven were oriented with their heads to the southeast. Two contained two individuals, while the others were single interments. No Middle Caddoan burials have been recovered from the White Oak Creek area.

Sites with calibrated radiocarbon dates which seem to place them within the Middle Caddoan period (A.D. 1200-1400) in the lower Sulphur River basin include Knight's Bluff and the Coker Mound (41CS1) at Wright Patman Lake; and 41CS150, 41CS155/156, 41BW553, and 41TT670 in the White Oak Creek Wildlife Management Area. Knight's Bluff has yielded two dates on charcoal of cal. A.D. 1307 (1408) 1441 (1-sigma) and cal. A.D. 1281 (1298) 1393 (1-sigma). ${ }^{1}$ The Coker Mound (41CS l) has yielded a date of cal. A.D. $1315-1345$ and 1390 (1405) 1420 (1-sigma). ${ }^{2}$

Of the sites in the White Oak Creek area, $41 \mathrm{CS} 150$ has yielded an AMS date of cal. A.D. 1300 (1395) 1415 (1-sigma) on hickory shell from a midden; 41CS155/156 has yielded an AMS date of cal. A.D. 1265 (1285) 1300 (1-sigma), also on hickory shell from a midden; 41BW553 has yielded an AMS date of cal. A.D. 1310-1365 and 1375 (1410) 1440 (1-sigma) also on hickory shell from a midden; and 41TT670 has yielded an AMS date of cal A.D. 1045-1105 and 1115 (1220) 1280 (1-sigma) on hickory shell from the base of a hearth. ${ }^{3}$ Site 41BW553 has also yielded an Oxidizable Carbon Ratio (OCR) date of A.D. 1337 (1354) 1371 (1-sigma) from a possible posthole; while 41TT670 has yielded OCR dates of A.D. 1243 (1263) 1283 and A.D. 1216 (1237) 1258 from a midden, and an OCR date of A.D. 1182 (1204) 1226 from the same hearth dated by radiocarbon (Largent et al. 1996).

In the Red River basin, the Middle Caddoan Haley focus is traditionally defined as containing the types Haley Engraved, Handy Engraved, and Haley Complicated Incised (most characteristic), as well as Crockett Curvilinear lncised, Dunkin Incised, East Incised, and Hickory Fine Engraved. Pease Brushed-Incised, Sinner Linear Punctated, and Kiam Incised may occur as minor types (Suhm et al. 1954:17I). At the Bell site, in the Little River area in Arkansas, the most common Middle Caddoan domestic pottery was apparently Pease Brushed-Incised (Wyckoff 1974). At the Knight's Bluff site, in the lower Sulphur River area, 15 vessels were recovered from nine burials (Jelks 1961:11-14). These included Pease Brushed-Incised ( 5 vessels), Nash Neck Banded (2 vessels), Haley 
Engraved (2 vessels), possible variants of Haley Engraved (2 vessels), Antioch Engraved (3 vessels), and Friendship Engraved (1 vessel). Antioch Engraved was a new bottle type described by Jelks as "small in size and careless of execution" with decoration "which consists of grotesque, disorderly patterns of circular, curved, and straight engraved lines" with "some crude hachuring" (Jelks 1961:29). With the exception of Friendship Engraved, Jelks suggested that these mortuary types were all resident at Knight's Bluff, as well as Barkman Engraved, McKinney Plain, Dunkin Incised, late variant, and a Baytown-like plainware, which were all present in some abundance in the midden at the site (Jelks 1961:11-41). Although most researchers today would probably not accept Jelks' argument that "the bulk of the artifacts from the entire site can be tentatively assigned to occupation by one snall village of people over a period of perhaps 10 to 50 years" (1961:22), a much stronger case can be made that the mortuary types present at the site are indeed, roughly contemporaneous, and representative of a late Middle Caddoan ceramic assemblage with a mixture of Haley phase and Texarkana phase types.

At the nearby Sherwin site (41CS26), a similar ceramic mortuary complex can be identified, although not associated with any radiocarbon dates (Jelks 1961:55-67). Seven burials at this site contained 11 vessels, including Pease Brushed-Incised (2 vessels), Nash Neck Banded (3 vessels), Haley Engraved (1 vessel), a possible variant of Haley Engraved ( 1 vessel), Higgins Engraved ( 2 vessels), and Maddox Engraved (2 vessels). Higgins Engraved was a tentative type identified by Jelks which he described as "mostly, or entirely" bottles, with "two or three horizontal engraved lines encircling the vessel just below the neck, with a series of small, closely spaced triangles pendent from the bottom line." which are placed "with apexes pointing downward, and...interiors...either excised or roughened with closely spaced scratches" (Jelks 1961:61). He concluded by saying that "the simple design is reminiscent of the type Haley Engraved of the Alto, Spiro, and Haley Foci [sic]." Using the midden sample, as well as the mortuary sample, Jelks concludes that "the principal resident types at the Sherwin Site seem to be, ...Barkman Engraved, Pease Brushed-Incised, Nash Neck Banded, and Baytown-like" (Jelks 1961:64), again suggesting a mixture of Haley and Texarkana phase types during the latter half of the Middle Caddoan period in this area.

Although Middle Caddoan ceramic samples from the White Oak Creek area are of small size and consist only of small sherds from non-mortuary contexts, they seem to show a vectored pattem of ceramic change during the Middle Caddoan period in this area. On the basis of these data, the Middle Caddoan period may be divisible into an early and a late phase, with a convenient break at A.D. 1300.

Two sites in the White Oak Creek area contain materials which can be dated to the first phase of the Middle Caddoan period in this area, from approximately A.D. 1200 to 1300. The first of these, $41 \mathrm{CS} 155 / 156$, contains a small domestic midden associated with a radiocarbon date from the early half of the Middle Caddoan period (Cliff and Hunt 1995). Tentatively identified ceramic types include Holly Fine Engraved, East (Davis?) Incised, Duren Neck Banded, and Weches Fingernail Impressed. Crockett Curvilinear Incised, Williams Plain, and a fragment of a Red River, var. Haley pipe were recovered from elsewhere on the site as well. At 41TT670, further to the west within the White Oak Creek basin, an AMS radiocarbon date and a series of OCR dates indicate the presence of a stratified midden which includes the early phase of the Middle Caddoan period (Largent et al. 1996). Ceramic types believed to be associated with this period at 41TT670 include Holly/Hickory Fine Engraved, Davis Incised, Williams Plain, and what seems to be an incised version of Williams Plain, for convenience called Williams Incised. In addition, one sherd each of what are identified as Pease Brushed-Incised and Sinner Linear Punctated suggest the appearance of these types by the end of this period.

A late phase of the Middle Caddoan period in the White Oak Creek area, dated as A.D. 1300 to 1400 , appears to be present at $41 \mathrm{CS} 150$ and $41 \mathrm{BW} 553$, based on radiocarbon and OCR dates (Cliff and Hunt 1995; Largent et al. 1996). Site 41CS150 contains the best evidence for this phase. Pease Brushed-Incised is the most frequent type 
present at this site, comprising 55 percent of the identifiable types there. Also present are what are identified as Hickory Fine Engraved, Holly Fine Engraved, Crockett Curvilinear Incised, East (Davis?) Incised, Sinner Linear Punctated, and Dunkin (Canton?) Incised (Cliff and Hunt 1995). At 41BW553, on the Sulphur River east of the confluence with White Oak Creek, a minor late Middle Caddoan component appears to be present, possibly associated with Pease Brushed-Incised, McKinney Plain, and a Red River, var. Haley pipe fragment (Largent et al. 1996).

The ceramic and chronological data from the White Oak Creek and Wright Patman Lake sites are summarized in Table 1 . The model that emerges is one of both temporal and spatial variability in ceramic assemblages during the Middle Caddoan period in the Lower Sulphur River area. The data suggest that some ceramic types that are generally considered earlier than the Middle Caddoan period, such as Crockett Curvilinear Incised, Holly Fine Engraved, Duren Neck Banded, Weches Fingernail Impressed, and Williams Plain continued into the early part of the Middle Caddoan and were gradually replaced by more recognizably later types, such as Haley Engraved, Hickory Fine Engraved, Dunkin Incised, Pease Brushed-Incised, and Sinner Linear Punctated. With larger excavated samples from the White Oak Creek area, it may be possible to see changes in the proportional representation of these types through time; but presently all that can be said with any certainty is that in this area, Pease Brushed-Incised was present in low frequencies by A.D. 1300 , and became the dominant utility ware type during the succeeding 100 years. During the later phase of the Middle Caddoan period, conveniently dated between A.D. 1300 and 1400, what are usually considered to be later types, such as McKinney Plain, Barkman Engraved, and Nash Neck Banded may have first appeared, becoming dominant during the subsequent Late Caddoan period.

These data also suggest that significant spatial variation existed within the Lower Sulphur River area, at least during the late phase of the Middle Caddoan period. In comparison to the sites in the White Oak Creek area (which have been formally designated as the "western facet" in Table 1), the sites in the Wright Patman area (the "eastern facet") seem to show more ties to the traditional Haley phase (i.e., Haley Engraved bottles), the more rapid incorporation of presumably newer types (i.e., Barkınan Engraved, Avery Engraved, and Simms Engraved), and probably a higher level of ceramic experimentation (i.e., Jelks' variants of Haley Engraved and the tentative new types Antioch Engraved and Higgins Engraved). It may be that the sites of the "eastern facet" of the late Middle Caddoan period represent social groups that were more closely linked to developments at important centers to the east, within the Red River basin proper (such as the Haley site), and that were more receptive to innovations originating in that area. Conversely; the sites of the "western facet" of the late Middle Caddoan may represent more isolated social groups which were slower to receive ceramic innovations from the Red River basin. Implicit in this view is the idea that the Red River basin was a center for ceramic and cultural innovation during the Caddoan period, with outlying areas (such as White Oak Creek) being more culturally peripheral.

\section{Endnotes}

1. These dates are reported in Pearson et al. (1966:462), Wyckoff (1974:122), and Story (1990:330). They are calibrated using CALIB (Stuiver and Reimer 1993).

2. This date (Beta-92919) is supplied by Dr. Tim Perttula, using calibrations based on Stuiver et al. (1993, eds.).

3. All of the White Oak Creek dates have been run by Beta Analytic, Inc., using the Stuiver et al. (1993, eds.) calibration. The dates for 41CS150 and 41CS155/156 are presented in Cliff and Hunt (1995); the dates for 41BW553 and 41TT670 are presented in Largent et al. (1996). 
Table 1

Tentative Middle Caddoan Ceramic Chronology for the Lower Sulphur River Area

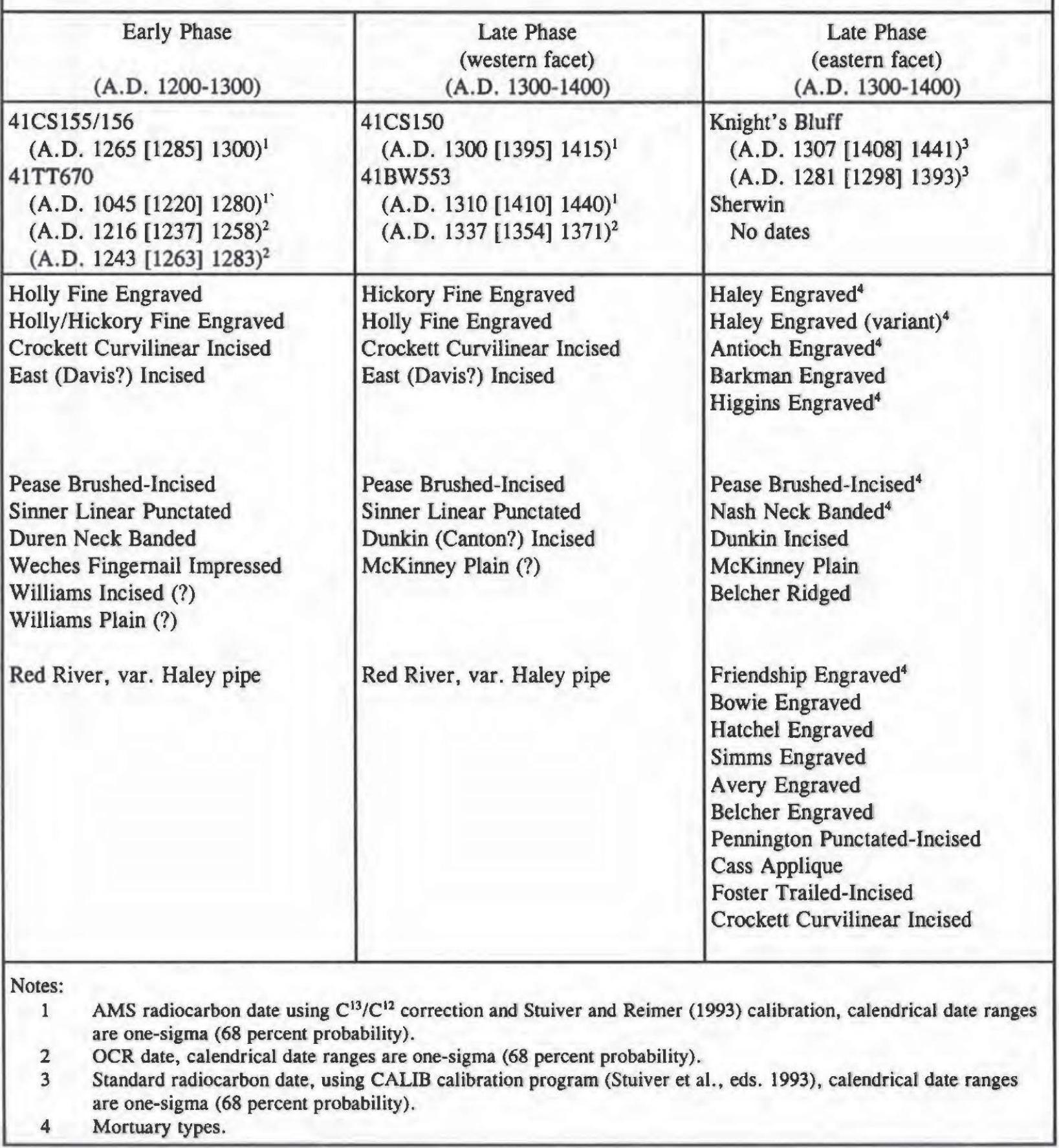




\section{References Cited}

Cliff, M. B., and S. M. Hunt

1995 Cultural Resources Testing of Three Sites within the Moist Soils Management Area (MSMA) of the White Oak Creek Mitigation Area (WOCMA), Cass County, Texas. White Oak Creek Mitigation Area Archeological Technical Series, Report of Investigations Number 3. Geo-Marine, Inc., Plano, Texas.

Davis, E. M.

1970 Archaeological and Historical Assessment of the Red River Basin in Texas. In Archeological and Historical Resources of the Red River Basin, edited by H. A. Davis, pp. 25-65. Research Series No. 1. Arkansas Archeological Survey, Fayetteville.

Jelks, E. B.

1961 Excavations at Texarkana Reservoir, Sulphur River, Northeastern Texas. River Basin Survey Papers No. 21, Bulletin No. 179. Bureau of American Ethnology, Washington, D.C.

Krieger, A. D.

1946 Culture Complexes and Chronology in Northern Texas. Publication No. 4640. University of Texas, Austin.

Largent, F. B., D. L. Beene, M. B. Cliff, and S. M. Hunt

1996 Cultural Resources Testing of Two Sites within the White Oak Creek Wildlife Management Area, Bowie and Titus Counties, Texas. Draft report prepared for the Fort Worth District, U.S. Army Corps of Engineers, by Geo-Marine, Inc., Plano.

Newell, H. P., and A. D. Krieger

1949 The George C. Davis Site, Cherokee County, Texas. Memoir No. 5. The Society for American Archaeology, Menasha, Wisconsin.

Pearson, F. J., E. M. Davis, and M. A. Tamers

1966 University of Texas Radiocarbon Dates IV. Radiocarbon 8:453-466.

Perttula, T. K. (compiler)

1993 Mound Sites in Northeast Texas and Northwest Louisiana. In Archeology in the Eastern Planning Region, Texas: A Planning Document, edited by N. A. Kenmotsu and T. K. Perttula, pp. 251-252. Cultural Resource Management Report 3. Texas Historical Commission, Austin.

Perttula, T. K., J. E. Bruseth, N. A. Kenmotsu, and W. A. Martin

1995 Archeological Testing at the Cabe Mounds (41BW14), Bowie County, Texas. Cultural Resource Management Report 8. Department of Antiquities Protection, Texas Historical Commission, Austin.

Story, D. A.

1990 Cultural History of the Native Americans. In The Archeology and Bioarcheology of the Gulf Coastal Plain, by D. A. Story, J. A. Guy, B. A. Burnett, M. D. Freeman, J. C. Rose, D. G. Steele, B. W. Olive, and K. J. Reinhard, pp. 163366. 2 Vols. Research Series No. 38. Arkansas Archeological Survey, Fayetteville.

Stuiver M., A. Long, R. S. Kra, and J. M. Devine (editors)

1993 Calibration-1993. Radiocarbon 35, No. 1. 
Stuiver, M., and P. J. Reimer

1993 Extended 14C Data Base and Revised Calib 3.0 14C Age Calibration Program. Radiocarbon 35(1):215-230.

Suhm, D. A., A. D. Krieger, and E. B. Jelks

1954 An Introductory Handbook of Texas Archeology. Bulletin of the Texas Archeological Society 25 (whole volume).

Wyckoff, D. G.

1974 The Caddoan Cultural Area: An ArchaeologicalPerspective. In Caddoan Indians I, pp. 25-279. Garland Publishing, Inc., New York. 